\title{
Feeding ecology of Auchenipterichthys longimanus (Siluriformes: Auchenipteridae) in a riparian flooded forest of Eastern Amazonia, Brazil
}

\author{
Tiago Magalhães da Silva Freitas¹, Vitor Hudson da Consolação Almeida², \\ Roberta de Melo Valente ${ }^{3}$ and Luciano Fogaça de Assis Montag ${ }^{2}$
}

Feeding habits of the midnight catfish Auchenipterichthys longimanus collected in rivers of the Caxiuanã National Forest (Eastern Amazonia, Brazil) were investigated through the different hydrological periods (dry, filing, flood and drawdown). A total of 589 specimens were collected throughout seven samplings between July 2008 and July 2009, of which 74 were young males, 177 adult males, 89 young females and 249 adult females. The diet composition (Alimentary index - Ai\%) was analyzed by a non-metric multidimensional scaling (nMDS) and by the analysis of similarity (ANOSIM), which included 37 items grouped into nine categories (Aquatic insects, Other aquatic invertebrates, Arthropods fragment, Fish, Plant fragment, Seeds, Terrestrial insects, Other terrestrial invertebrates, and Terrestrial vertebrates). We also calculated the niche breadth (Levins index) and the repletion index (RI\%). Differences in the diet composition between hydrological seasons were registered, primarily on diet composition between dry and flood season, but changes related with sex and maturity were not observed. The midnight catfish showed more specialists feeder habit in the flood period (March 2009) and more generalist habits in the dry season (November 2008). The amount of food eaten by A. longimanus based on repletion index (RI\%), did not differ significantly from sex and maturity. However, we evidenced differences in RI\% when comparing the studied months. These results provide important biological information about the trophic ecology of auchenipterids fish. In view of the higher occurrence of allochthonous items, this research also underpins the importance of riparian forests as critical environments in the maintenance and conservation of wild populations of fish in the Amazon basin.

Neste estudo foram investigados os hábitos alimentares do bagre Auchenipterichthys longimanus coletados em rios da Floresta Nacional de Caxiuanã (Amazônia Oriental, Brasil) ao longo de diferentes períodos hidrológicos (seco, enchendo, cheio e vazando). Foram coletados 589 espécimes durante sete amostragens, entre julho de 2008 e julho de 2009, dos quais 74 eram machos jovens, 177 machos adultos, 89 fêmeas jovens e 249 fêmeas adultas. A composição da dieta, analisada pelo Índice de Importância Alimentar (IAi\%) foi avaliada por um escalonamento multidimensional não-métrico (nMDS) e pela análise de similaridade (ANOSIM), que incluiu 37 itens alimentares agrupados em nove categorias (insetos aquáticos, outros invertebrados aquáticos, fragmento de artrópodes, peixe, fragmento de planta, sementes, insetos terrestres, outros invertebrados terrestres e vertebrados terrestres). Também foram obtidos a amplitude de nicho (Índice de Levins) e o Índice de Repleção (IR\%) da dieta do bagre. Foram observadas diferenças na composição da dieta entre os períodos hidrológicos, principalmente relacionada à estação seca e cheia, mas não houve variação na composição da dieta entre os sexos e maturidade. No período de cheia (especificamente no mês de março/2009) o bagre mostrou uma alimentação mais especialista enquanto que no período de seca (novembro/2008) os valores de amplitude de nicho classificaram-no com hábitos mais generalistas quanto a alimentação. A quantidade de alimentos ingeridos por $A$. longimanus com base no Índice de Repleção (IR\%), não diferiram significativamente entre o sexo e maturidade. No entanto, foram evidenciadas diferenças quando comparados os meses estudados. Estes resultados fornecem informações biológicas importantes sobre a ecologia trófica de peixes da família Auchenipteridae. Tendo em vista a maior ocorrência de itens alóctones na dieta deste bagre, esta pesquisa também reforça a importância das matas ciliares em ambientes críticos na manutenção e conservação das populações selvagens de peixes na bacia amazônica.

Key words: Amazon, Catfish, Hydrological seasons, Trophic ecology.

${ }^{1}$ Universidade Federal do Pará, Campus Universitário do Marajó, Faculdade de Ciências Naturais. Conjunto Bandeirante, Aeroporto, 68800-000, Breves, PA, Brazil. freitastms@gmail.com

${ }^{2}$ Universidade Federal do Pará, Instituto de Ciências Biológicas, Laboratório de Ecologia e Zoologia de Vertebrados. Rua Augusto Corrêa, 01, Guamá,66075-110, P.O. Box 479 Belém, PA, Brazil.condevitor@yahoo.com.br; lfamontag@gmail.com

${ }^{3}$ Universidade Federal do Pará, Instituto de Ciências Biológicas, Laboratório de Invertebrados. Rua Augusto Corrêa, 01, Guamá, 66075110, P.O. Box 479, Belém, PA, Brazil.rvalente@ufpa.br 


\section{Introduction}

The midnight catfish Auchenipterichthys longimanus (Günther, 1864), belonging to the family Auchenipteridae, is a Neotropical endemic species, with wide distribution in the Amazon and Orinoco basins (Ferraris et al., 2005). Most species of this family is omnivorous, nocturnal habit and are active swimmers in the water column (Rodrigues et al., 1990; Ferraris, 2003). During the night, these fish can be seen swimming just below the water surface in search of insects that fall from the riparian vegetation (Ferraris, 2003).

In eastern Amazonia, this species is very abundant in flooded environments, called várzea or igapó (Merona et al., 2001; Lin \& Caramaschi, 2005; Montag, 2006). These environments are formed during the rainy season which the high water level inundates the riparian forest (Barthem \& Goulding, 2007). In these environs several species of fish search for shelter and food supply, such as insects, fruits and seeds (e.g. Gottsberger, 1978; Goulding, 1980; Saint-Paul et al., 2000; Claro-Jr. et al., 2004).

Thus, the feeding habit of fishes can be highly influenced by seasonal hydrological changes in the environment (e.g. Winemiller, 1989; Wootton, 1998, Lowe-McConnell, 1987) and further studies on the dietary ecology contributed to the understanding of the relationship between the aquatic fauna and the riparian forests (Winnemiller, 1989, Layman et al., 2007)

For Vidotto-Magnoni \& Carvalho (2009), the analysis of fish diets is also essential to better understand the ecology and behavior of the species, as well as other aspects, namely reproduction, growth and population dynamics (Andrian \& Barbieri, 1996; Ballesteros et al., 2009). Dietary ecology and feeding habits can be explored by quantifying variation in resource use, trophic niche breadth and feeding intensity (Hammerschlag et al., 2010). These aspects, in the other hand, are influenced by food availability, food diversity, competition, and abiotic factors such as water level changes.

Starting from the hypothesis that fish feeding is influenced by hydrological seasons, the aim of this study was, therefore, to assess the feeding ecology of midnight catfish $A$. longimanus from rivers of Caxiuanã National Forest in the Eastern Amazonia, Brazil, through the different hydrological periods (dry, filing, flood and drawdown). In this area, $A$. longimanus is one of the most abundant species (Montag et al., 2008), and understanding the trophic ecology of this species will bring important information on the auchenipterids biology.

\section{Material and Methods}

\section{Study area}

The sampling were carried out in the rivers of the Caxiuanã National Forest ( $\left.1^{\circ} 45^{\prime} 27.5^{\prime \prime} \mathrm{S} 51^{\circ} 27^{\prime} 33.2^{\prime \prime} \mathrm{W}\right)$, which is located in the Eastern Amazonia, between the Xingu and Tocantins Rivers in the municipalities of Melgaço and Portel, State of Pará, Brazil (Fig. 1).

The region is described as a lowland amazon rainforest located at sea level, being influenced both by the tide and by

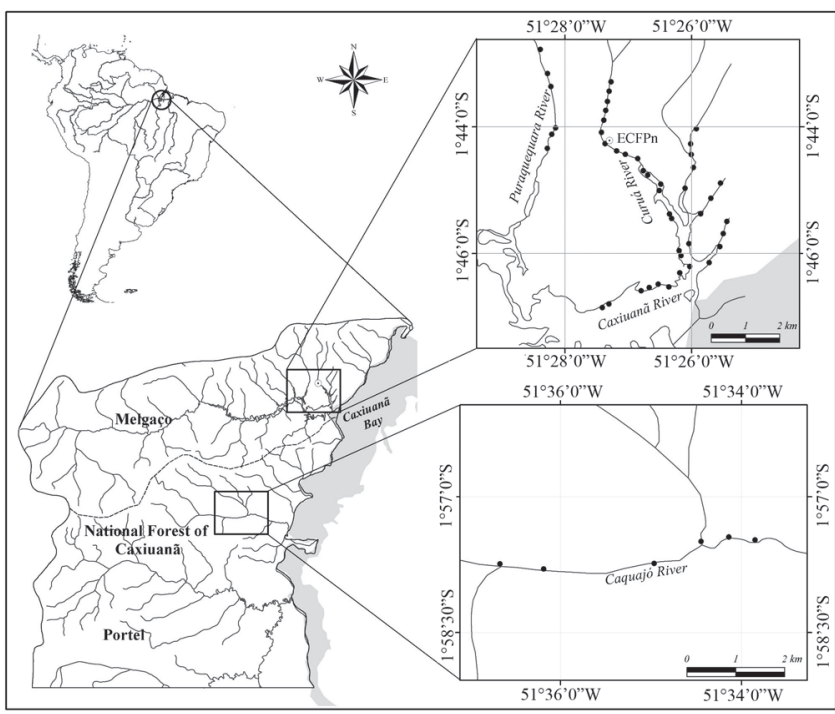

Fig. 1. Location of the Caxiuanã National Forest, showing the rivers where the fish were collected. Curuá River - Ferreira Penna Research Station (ECFPn), Caxiuanã River, Puraquequara River and Caquajó River. Some black spots represent more than one collection site.

the oscillation of Anapu River (Hida et al., 1999). However, both flows have very low intensity, with an annual fluctuation in the water level only about one meter (Hida et al., 1999). In the region it could be observed four hydrological period by the fluviometry (Fig. 2): drawdown (June-August), dry (SeptemberNovember), filling (December-February) and flood (MarchMay).

Because of a geological event of valleys drowning of the Anapu River, the region is also defined as "ria fluvial", showing a slight floodplain even during the flood period (Costa et al., 2002).

\section{Fish sampling}

Bimonthly collections were carried out between July 2008 and July 2009 in rivers of the Caxiuanã National Forest, assessing the annual hydrological cycle (drawdown, dry, filling and flood). We used gill nets, on average, $1.5 \mathrm{~m}$ high and $100 \mathrm{~m}$ long, with three to six centimeter meshes between opposite knots. The sites where the nets were located were selected with the help of a local fisherman. After capturing, the individuals were measured (total length in $\mathrm{cm}$ ), weighed (total mass in g), sexed and their stomachs were removed through a cut in the mid-ventral region. The stomachs were weighed ( $0.001 \mathrm{~g}$ precision) and kept in $10 \%$ formalin for 24 hours, and then preserved in $70 \%$ alcohol.

The midnight catfish specimens were deposited in the ichthyology collection of the Museu Paraense Emílio Goeldi MCT/MPEG (Pará, Brazil), with the following voucher sequences: MPEG 15257 to 15259 , MPEG 15260 to 15264 , MPEG 15432 to 15442 , MPEG 15498 to 15507 , MPEG 15544 to 15555 , MPEG 15844 to 15860 , and MPEG 16221 to 16231. 


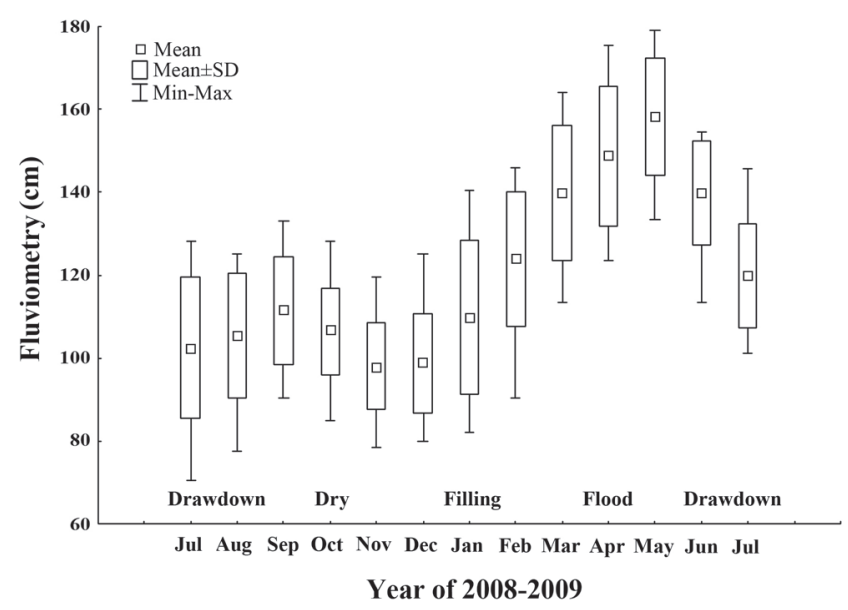

Fig. 2. Fluviometry from the rivers of the Caxiuanã National Forest in the period between July 2008 and July 2009. Data obtained from the fluviometric station of Caiçara of the National Water Agency (ANA).

\section{Data analysis}

The specimens were grouped by sex, maturity and hydrological period. On maturity, the fish were classified as young or adults according to the estimated size at first maturity for A. longimanus obtained by Freitas (2010), which classifies as adults any male larger than $12.5 \mathrm{~cm}$ and female larger than $13.0 \mathrm{~cm}$.

The stomach contents were identified to the most precise taxonomic category possible, using a stereomicroscope (Nikon, model SMZ-10; 40x precision) and available literature. For each item we calculated the frequency of occurrence (FO\%; Hyslop, 1980 ) and mass percentage (M\%; Hynes, 1950), which was obtained by weighing each item and then calculating its importance among the total weight of all items. These two parameters (FO $\%$ and $\mathrm{M} \%$ ) were combined into the Alimentary Index (Ai\%; modified from Kawakami \& Vazzoler, 1980), which finally attributes the importance of the items in the diet. The $\mathrm{Ai} \%$ was calculated by the equation $\mathrm{Ai} \%=(\mathrm{FO} \% * \mathrm{M} \% / \Sigma \mathrm{FO} \%$ *M\%)*100 and the empty stomachs were not included in the analysis.

The food items were grouped into nine categories (aquatic insects, other aquatic invertebrates, arthropods fragment, fish, plant fragment, seeds, terrestrial insects, other terrestrial invertebrates, and terrestrial vertebrates) and had their respective values of $\mathrm{Ai} \%$ calculated.

Non-metric multidimensional scaling (nMDS) ordinations were based in a cluster analysis using Unweight Paired Group Method by Mathematical Average - UPGMA (Romesbeirg, 1984) and the Bray-Curtis similarity matrices (Clarke \& Warwick, 2001). The nMDS computes the distortion, or stress, between the similarity matrix and the ordination produced in a graphic representation of the axes.

The analysis of similarities (ANOSIM) was used to test the null hypothesis $\left(\mathrm{H}_{0}\right)$ that there were no significant differences in the diet composition between sex, maturity and hydrological period with a significance level of 0.05 . In this analysis, we calculated the R-statistic, a comparative measure of the separation degree of the samples, which will permeate the decision of acceptance or rejection of $\mathrm{H}_{0}$. The range of variation of $\mathrm{R}$ is -1 to 1 , which values near zero mean acceptance of $\mathrm{H}_{0}$. Both nMDS and ANOSIM was performed in the statistical software PRIMER 6 (Clarke \& Gorley, 2006).

The Ai\% values were exploratory applied in the niche breadth (range of the diet) using the standardized Levins index (Hurlbert, 1978). This was given by the equation $\mathrm{B}_{\mathrm{a}}=\left[\left(\Sigma_{\mathrm{j}} \mathrm{P} 2_{\mathrm{ij}}\right)^{-}\right.$ $\left.{ }^{1}-1\right]^{*}(n-1)^{-1}$, where $B_{a}=$ standardized niche breath; $P_{i j}=$ proportion of prey $j$ in the diet of predator $i$ and $\mathrm{n}=$ total number of prey consumed by a particular predator. This index ranges from 0 , when a species consumed only one type of prey (specialist consumer) to 1, when a species consumed many types of prey similarly (generalist consumer).

Finally, we performed a repletion index (RI\%; Zavala-Camin, 1996) using the expression modified from Santos (1979): RI\% = $\left(\Sigma \mathrm{W}_{\mathrm{i}} / \mathrm{W}_{\mathrm{t}}\right) * 100$, where $\Sigma \mathrm{W}_{\mathrm{i}}$ is the sum of the food content of individual $\mathrm{i} ; \mathrm{W}_{\mathrm{t}}$ is the total weight of individual $\mathrm{i}$. The repletion index was analyzed individually for sex, maturity and collection periods (months). To investigate differences in the amount of food eaten by sex and maturity, the variation of the RI\% was evaluated for the $t$ test with a significance level of 0.05 . The monthly results obtained for the RI\% were assessed by the nonparametric Kruskal-Wallis $(\mathrm{H})$ tested at a probability level of 0.05 , considering as the null hypothesis $\left(\mathrm{H}_{0}\right)$ that the diet of A. longimanus is independent of period.

\section{Results}

Throughout the seven campaigns, 589 stomachs of $A$. longimanus were analyzed, of which 74 were from young males, 177 from adult males, 89 from young females and 249 from adult females. We identified 37 food items, most of allochthonous origin (Table 1). The proportion of empty stomachs represented $15-30 \%$ between the classes and was not included in the $\mathrm{Ai} \%$ analysis.

In general, the diet of the midnight catfish was composed of terrestrial insects $(\mathrm{Ai} \%=50.5 \%)$, Arthropods fragments $(28.7 \%)$, seeds $(13.0 \%)$, and plant fragment $(6.2 \%)$; the remaining categories (Aquatic insects, Other aquatic invertebrates, Other terrestrial invertebrates, Fish and Terrestrial vertebrates) accounted less than $2 \%$ for the diet.

Among terrestrial insects, Lepidoptera were the most consumed item in the diet of $A$. longimanus ( $\mathrm{Ai} \%=9.1 \%$ ), followed by Formicidae (8.6\%) and Orthoptera (3.7\%). The arthropods fragments represented the terrestrial arthropods remains that were not possible to identify. Among the seeds, seeds of Virola surinamensis represented $15.2 \%$ of the diet composition of the midnight catfish even considering that this item appears only twice (January and March; see Table 1).

The stress obtained with the ordination (nMDS) was 0.02 , which ensures good consistency of the results. The diet composition of $A$. longimanus did not show a clear pattern of separation between sex and maturity (ANOSIM, all P $>0.05$ ). 
Table 1. Alimentary Index (Ai\%) of food items in the diet of the midnight catfish Auchenipterichthys longimanus from river of the Caxiuanã National Forest (PA, Brazil) from July 2008 to July 2009.

\begin{tabular}{|c|c|c|c|c|c|c|c|c|}
\hline \multirow{3}{*}{ Food Itens } & \multicolumn{3}{|c|}{2008} & \multicolumn{4}{|c|}{2009} & \multirow{3}{*}{ General } \\
\hline & \multirow{2}{*}{$\begin{array}{c}\text { Drawdown } \\
\text { July }\end{array}$} & \multicolumn{2}{|c|}{ Dry } & \multirow{2}{*}{$\begin{array}{l}\text { Filling } \\
\text { January } \\
\end{array}$} & \multicolumn{2}{|c|}{ Flood } & \multirow{2}{*}{$\begin{array}{c}\text { Drawdown } \\
\text { July }\end{array}$} & \\
\hline & & September & November & & March & May & & \\
\hline \multicolumn{9}{|l|}{ Animal (Allochthonous) } \\
\hline Terrestrial insects & 43.85 & 13.62 & 43.15 & 50.45 & 10.72 & 66.21 & 63.54 & 50.48 \\
\hline Blattodea & 0.1 & - & 0.6 & 0.7 & 0.1 & 0.8 & 0.1 & 0.2 \\
\hline Coleoptera terrestrial & 0.6 & 0.4 & 0.4 & 5.7 & 0.1 & 1.8 & 1.1 & 1.3 \\
\hline Diptera terrestrial & - & - & 0.0 & 0.0 & 0.0 & 0.0 & 0.0 & 0.0 \\
\hline Formicidae & 19.2 & 4.1 & 12.9 & 9.6 & 1.7 & 16.1 & 4.3 & 8.6 \\
\hline Hemiptera & 0.1 & 0.6 & 6.9 & 0.9 & 0.0 & 1.2 & 0.1 & 0.3 \\
\hline Homoptera & 0.2 & 0.6 & - & 0.0 & 0.0 & 0.3 & 0.2 & 0.2 \\
\hline Hymenoptera & 0.0 & 0.0 & 0.3 & 1.3 & 0.3 & 0.8 & 0.0 & 0.3 \\
\hline Isoptera & 2.0 & 0.0 & - & 0.3 & 0.0 & 0.0 & 0.4 & 0.3 \\
\hline Lepidoptera & 3.1 & 0.3 & - & 0.3 & 0.0 & 6.6 & 36.5 & 9.1 \\
\hline Neoroptera (larvae) & - & - & - & - & - & 0.1 & - & 0.0 \\
\hline Odonata & 0.0 & - & - & - & - & 0.1 & 0.0 & 0.0 \\
\hline Orthoptera & 0.2 & 1.5 & - & 4.8 & 1.2 & 7.1 & 3.7 & 3.7 \\
\hline Arthropods fragment & 28.3 & 13.00 & 35.02 & 33.41 & 8.23 & 27.29 & 33.47 & 28.72 \\
\hline Arthropods fragment & 38.0 & 30.0 & 54.8 & 60.9 & 10.0 & 55.3 & 51.2 & 52.2 \\
\hline Other terrestrial invertebrates & 0.85 & 0.11 & 1.66 & 0.84 & 0.12 & 1.16 & 1.70 & 1.10 \\
\hline Annelida & - & - & - & 0.3 & - & - & 0.2 & 0.1 \\
\hline Arachnida (Aranae) & 0.4 & 0.7 & 1.1 & 0.0 & 0.2 & 2.1 & 0.1 & 0.4 \\
\hline Arachnida (Scorpiones) & - & - & - & 0.2 & - & - & 0.1 & 0.0 \\
\hline Crustacea (Isopoda) & - & - & - & 0.0 & - & - & - & 0.0 \\
\hline Myriapoda (Chilopoda) & 0.1 & - & 0.2 & - & - & - & 0.2 & 0.1 \\
\hline Myriapoda (Diplopoda) & - & - & - & - & - & - & - & 0.0 \\
\hline Terrestrial vertebrates & 0.04 & - & 6.39 & - & - & 0.07 & 0.01 & 0.02 \\
\hline Amphibia (Anura) & - & - & 10.0 & - & - & - & - & 0.0 \\
\hline Squamata (exuvie of the Ophidia) & - & - & - & - & - & - & 0.0 & 0.0 \\
\hline Squamata (Sauria) & 0.0 & - & - & - & - & 0.1 & - & 0.0 \\
\hline \multicolumn{9}{|l|}{ Plant (Allochthonous) } \\
\hline Plant fragment & 25.83 & 73.21 & 8.16 & 6.98 & 2.18 & 1.76 & 1.01 & 6.23 \\
\hline Plant fragments & 35.0 & 8.7 & 4.2 & 9.1 & 1.4 & 0.5 & 1.5 & 6.0 \\
\hline Plant fragments (Flower) & & 52.7 & 1.0 & 0.4 & 0.3 & 0.8 & 0.0 & 1.0 \\
\hline Seeds & 0.00 & - & - & 7.77 & 78.73 & 2.66 & - & 13.04 \\
\hline Plant fragments (Seed) & 0.0 & - & - & 0.5 & 0.5 & 5.4 & - & 0.5 \\
\hline Seeds of Virola surinamensis & - & - & - & 4.4 & 84.1 & - & - & 15.2 \\
\hline \multicolumn{9}{|l|}{ Animal (Autochthonous) } \\
\hline Aquatic insects & 0.13 & 0.00 & 2.04 & - & 0.00 & 0.00 & 0.07 & 0.03 \\
\hline Coleoptera aquatic & 0.0 & - & 2.0 & - & - & 0.0 & 0.0 & 0.0 \\
\hline Diptera aquatic & 0.0 & 0.0 & - & - & - & - & 0.0 & 0.0 \\
\hline Ephemeroptera daphne & - & - & - & - & - & - & 0.0 & 0.0 \\
\hline Odonata daphne & - & - & 0.1 & - & 0.0 & - & 0.0 & 0.0 \\
\hline Other aquatic invertebrates & 0.88 & 0.05 & 0.44 & 0.32 & 0.02 & 0.47 & 0.14 & 0.23 \\
\hline Crustacea (Brachyura) & - & 0.0 & - & 0.1 & 0.0 & 0.0 & - & 0.0 \\
\hline Crustacea (Caridea) & 0.9 & 0.0 & 0.7 & 0.2 & - & 0.2 & 0.2 & 0.2 \\
\hline Mollusca & - & - & - & - & - & 0.2 & 0.0 & 0.0 \\
\hline Fish & 0.12 & 0.05 & 0.44 & 0.23 & 0.00 & 0.38 & 0.06 & 0.13 \\
\hline Characidae & - & 0.2 & 4.9 & 0.1 & - & 0.1 & 0.0 & 0.0 \\
\hline Fish Fragments & 0.1 & 0.0 & - & 0.0 & 0.0 & 0.1 & 0.0 & 0.0 \\
\hline Synbranchidae & - & - & - & 0.1 & - & 0.1 & - & 0.0 \\
\hline Inorganic material & 0.1 & - & - & - & 0.0 & 0.3 & - & 0.0 \\
\hline
\end{tabular}

Moreover, the ANOSIM showed a significant difference in the diet related to the hydrological period $(\mathrm{R}=0.148, \mathrm{P}=0.057)$, primarily on diet composition between dry and flood season $(\mathrm{R}=0.545, \mathrm{P}=0.015$, Table 2$)$. The multivariate analysis (nMDS) was based in $50 \%$ of similarity, which basically separated the dry and flood elements of the feeding analysis (Fig. 3).

In the dry season the diet of the $A$. longimanus was mainly composed of plant fragment (September, $\mathrm{Ai} \%=73.2 \%$ and November, $8.2 \%$ ) and terrestrial insects (Sep $=13.6 \%$ and $\mathrm{Nov}=$ $8.2 \%$ ) while in the flood season the feeding analysis revealed seeds (March, $\mathrm{Ai} \%=78.7 \%$ and $\mathrm{May}, \mathrm{Ai} \%=2.7 \%$ ) and terrestrial insects (Mar $=10.7 \%$ and $\mathrm{May}=66.2 \%$ ) as principal items (Fig. 3).

The ANOSIM also revealed differences in the diet composition between the drawdown and dry season $(\mathrm{R}=0.313$, $\mathrm{P}=0.034$, Table 2), with terrestrial insects and arthropods fragment as primary items in the feeding of the $A$. longimanus in drawdown season.

The niche breadth (Levins index) of the midnight catfish varied considerably between months (Fig. 4). The highest values were observed in November/2008 $\left(\mathrm{B}_{\mathrm{a}}=0.409\right.$; dry season) and May/2009 $\left(\mathrm{B}_{\mathrm{a}}=0.336\right.$; flood season) because of the importance given to many item in feeding in those months (Table 1). The lowest values of Levins index was obtained in 


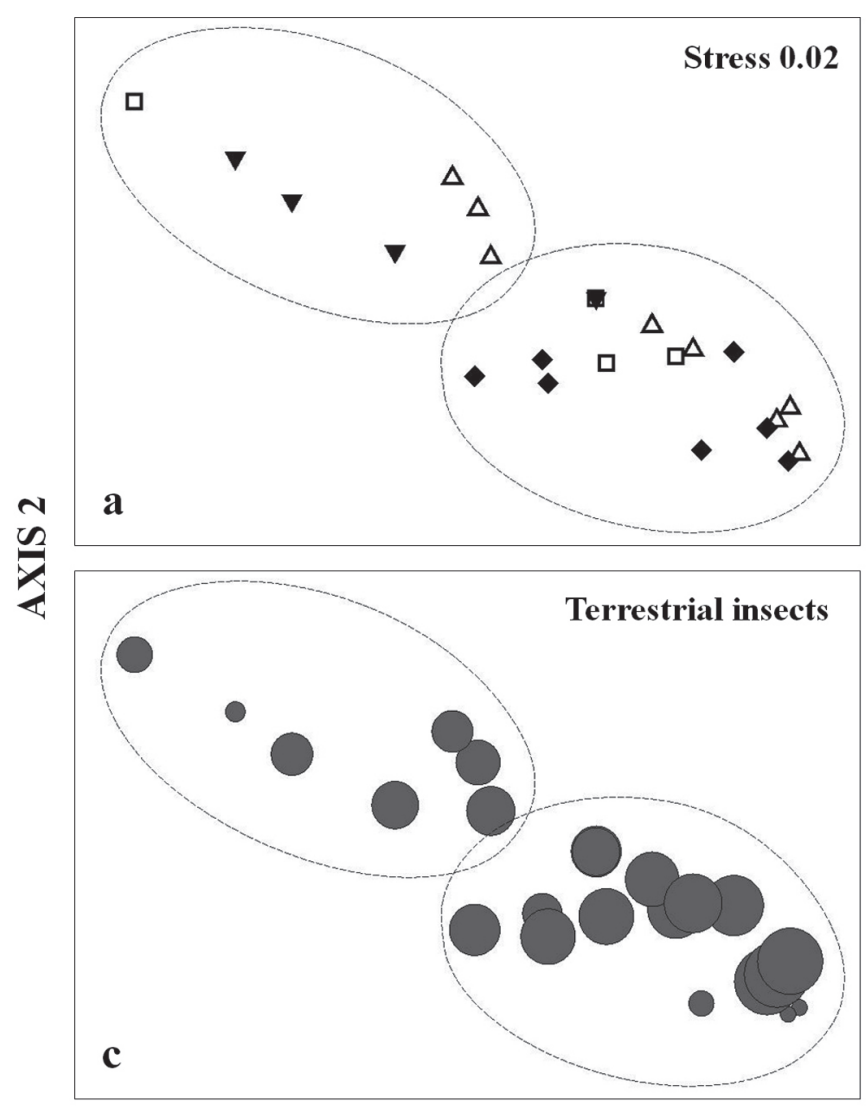

AXIS 1
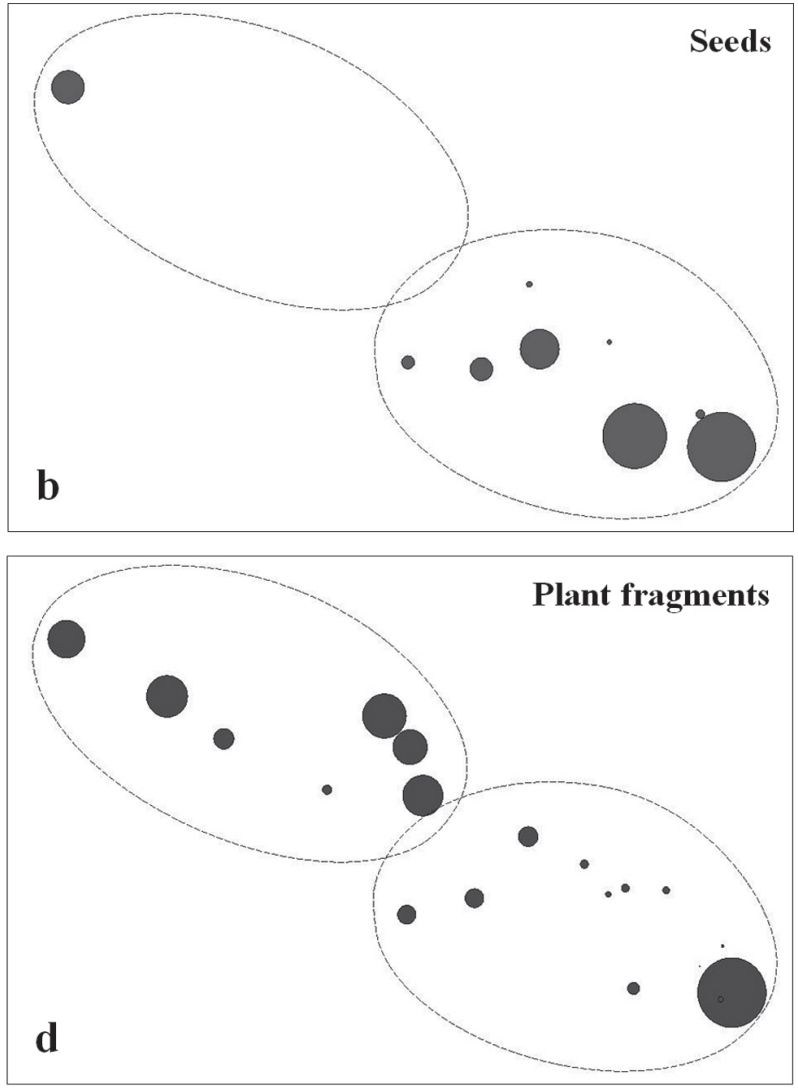

AXIS 1

Fig. 3. (a) Graphic representation of the non-metric multidimensional scaling analysis (NMDS) of the diet of Auchenipterichthys longimanus from rivers of the Caxiuanã National Forest (PA, Brazil). Stress $=0.02$. The geometric forms represent the hydrological seasons: $\Delta$ drawdown; $\boldsymbol{\Delta}$ dry; $\square$ filing; and $\bullet$ flood. (b-d) contribution (expressed according to the circle size) of the seeds (b), terrestrial insects (c) and plant fragment (d) in the feeding analysis.

$\operatorname{March} / 2009\left(\mathrm{~B}_{\mathrm{a}}=0.034\right)$ due the high consumption of one single item (seeds of Virola surinamensis, $\mathrm{Ai} \%=84.1 \%$; see Table 1 ).

The amount of food eaten by $A$. longimanus based on repletion index (RI\%), did not differ significantly from sex ( $\mathrm{t}=$ 1.965 , d.f. $=488, \mathrm{P}=0.206)$ either for maturity $(\mathrm{t}=1.964$, d. $\mathrm{f}=586, \mathrm{P}=$ $0.555)$. However, we evidenced differences in RI\% when comparing the months $\left(\mathrm{H}_{6,0.05}=51.35 ; \mathrm{P}<0.000\right)$. Using the MannWhitney pairwise comparison we observed differences on the $\mathrm{RI} \%$ in November of 2008 and May of 2009 with the other periods $(\mathrm{P}<0.05$; Table 3). The highest level of food ingestion were registered in January and March of 2009 (RI\%= $1.7 \pm 2.1 \%$ each; filling and flood season, respectively; Fig. 5) and the lowest values of RI\% were in November/2008 ( $0.3 \pm 0.6 \%$; dry season $)$ and May/2009 (0.8 $\pm 1.1 \%$; flood season; Fig. 5).

\section{Discussion}

According to the diet analysis of the midnight catfish $A$. longimanus, this species may be considered insectivorous, due to the high consumption of terrestrial insects and arthropods fragments in most studied months (July and
November 2008 and January, May and July 2009). However, if we analyze each collection period, this species could be classified as an omnivorous because its opportunistic frugivorous habits in September 2008 (dry season) and March 2009 (flood), consuming plant fragment as flowers and seeds, respectively. This kind of item that falls on the water from the riparian forest seems to be of easy capturing by $A$. longimanus because its water surface swimmer habit (Ferraris, 2003), which would explain the high consumption these plant parts.

Regarding the trophic ecology of auchenipterids, the feeding habits of $A$. longimanus are similar to those found for several species of the Family Auchenipteridae, such as Trachycorystes in the lowland region of the central Amazon basin (Manaus, State of Amazonas, Brazil) (Goulding, 1980); Tocantinsia in upper Tocantins River, Brazil (Carvalho \& Kawakami, 1984); Parauchenipterus (=Trachelyopterus) in a reservoir of the Paraná basin, Brazil (Andrian \& Barbieri, 1996) and in the northeastern Brazilian basins (Santos, 2005); and Auchenipterichthys, Auchenipterus, and Tatia in the basin of Anapu River (Montag, 2006). Andrian \& Barbieri (1996), for example, analyzed the feeding of Parauchenipterus galeatus 
Table 2. Pairwise comparison from ANOSIM between hydrological periods for the diet composition of the midnight catfish Auchenipterichthys longimanus from rivers of the Caxiuanã National Forest (PA, Brazil) from July 2008 to July 2009. *significant values for the test.

\begin{tabular}{lcc}
\hline Groups & R-statistic & $\begin{array}{c}\text { Significance level } \\
\text { (P-values) }\end{array}$ \\
\hline Drawdown/Dry & 0.313 & $0.034^{*}$ \\
Drawdown/Filling & 0.033 & 0.388 \\
Drawdown/Flood & -0.02 & 0.462 \\
Dry/Filling & 0.063 & 0.314 \\
Dry/Flood & 0.545 & $0.015^{*}$ \\
Filling/Flood & 0.079 & 0.279 \\
All seasons & 0.148 & $0.057^{*}$ \\
\hline
\end{tabular}

$(=T$. galeatus $)$ in a reservoir in southern Brazil and similarly noted the important contribution of terrestrial insects and plants in the auchenipterid diet.

Several studies also highlight the importance of these food items in the diet of Neotropical fishes (Waldhoff et al., 1996; Esteves \& Aranha, 1999; Abelha et al., 2001; Claro-Jr. et al., 2004; Vidotto-Magnoni \& Carvalho, 2009), which substantiates the importance of riparian forests for aquatic biological communities that seek other food sources in these ecosystems (Goulding, 1980).

Despite the constant importance of animal items in the diet of the midnight catfish between the months (terrestrial insects and arthropods fragments), seasonal changes in its diet showed in this study can be mostly related to the availability of plant items. In the flood period (March/2009) the seeds of Virola surinamensis were very abundant and represent the mainly item in the diet of $A$. longimanus. In that month the availability of this kind of seed also revealed two situations: the lowest values of niche breadth and the highest level of food consumption.

Within the flood period the water invaded the forest and theoretically supplies more food resource for fishes (Goulding, 1980; Gomiero et al., 2008). Nevertheless, in the flood period in

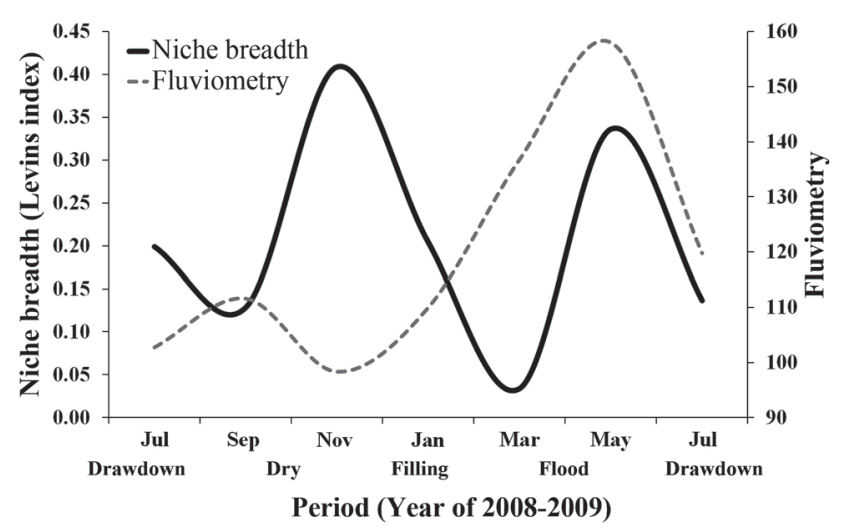

Fig. 4. Trophic niche breadth (Levins index; $\mathrm{B}_{\mathrm{a}}$ ) of the midnight catfish Auchenipterichthys longimanus from rivers of the Caxiuanã National Forest of (PA, Brazil) related to hydrological periods.
Table 3. Significance values for the Mann-Whitney pairwise comparison of Repletion Index (RI\%) of the midnight catfish Auchenipterichthys longimanus from rivers of the Caxiuanã National Forest (PA, Brazil). *significant values for the test.

\begin{tabular}{|c|c|c|c|c|c|c|c|c|}
\hline \multirow{3}{*}{\multicolumn{3}{|c|}{$\begin{array}{c}\text { Mann-Whitney } \\
\text { pairwise comparison }\end{array}$}} & & 2008 & \multicolumn{4}{|c|}{2009} \\
\hline & & & \multicolumn{2}{|c|}{ Dry } & Filling & \multicolumn{2}{|c|}{ Flood } & \multirow{2}{*}{$\begin{array}{l}\text { Drawdown } \\
\text { Jul }\end{array}$} \\
\hline & & & Sep & Nov & Jan & Mar & May & \\
\hline \multirow{3}{*}{2008} & Drawdown & Jul & 0.238 & $0.000 *$ & 0.291 & 0.136 & $0.038^{*}$ & $0.016^{*}$ \\
\hline & & Sep & & $0.044 *$ & 0.671 & 0.946 & $0.025^{*}$ & 0.552 \\
\hline & & Nov & & & $0.000 *$ & $0.000 *$ & $0.001 *$ & $0.003 *$ \\
\hline \multirow{3}{*}{2009} & Filling & Jan & & & & 0.534 & $0.001 *$ & 0.080 \\
\hline & & Mar & & & & & $0.004 *$ & 0.158 \\
\hline & & May & & & & & & $0.042 *$ \\
\hline
\end{tabular}

March/2009, the $A$. longimanus presented the most specialists feeding behavior. Already in May/2009 (still flood season) the low food intake may be related to the reproductive activity (Jan-May 2009) evidenced by Freitas (2010). The large consumption of seeds in March 2009 is also suggested by Freitas (2010) as an energy source for reproduction, and besides reinforcing the importance of riparian forests on the fish diet (Goulding, 1980) may also suggest an active role of the midnight catfish in seed dispersal (Mannheimer et al., 2003; Freitas, 2010).

Despite the relationship of feeding and fish reproduction is recognized in the literature (Bellesteros et al., 2009), it needs to be further investigated for $A$. longimanus in the Amazon rivers to improve our understanding of the diet role in the breeding of tropical fish.

In the dry season (November/2008), the feeding of $A$. longimanus was also strongly composed of plant fragments, flowers. However, this month presented the greatest niche breadth and the lowest level of food consumption. With the low water level, the rivers are not flooding the forest anymore and the fish that feeds on allochthonous items from the riparian forest has its food supply reduced (Goulding, 1980; Esteves \& Aranha, 1999; Gomieiro et al., 2008). Summarizing, the diet composition and food intake of $A$. longimanus from the Caxiuanã Nacional Forest rivers appears to be influenced by extrinsic factors such as hydrological seasons even knowing that the water level variation is described as slight (Costa et al., 2002). In fact, this variation seems to be enough to create mechanisms to adapt its biological processes such as reproduction.

By the way, seasonality changes in the feeding of fishes have been frequently documented in many studies (Claro-Jr. et al., 2004, Santos, 2005; Luz-Agostinho et al., 2009; Barnes et al., 2010; Tófoli et al., 2010). Within the auchenipterids, Santos (2005) analyzed the feeding habit of Parauchenipterus galeatus (= Trachelyopterus galeatus) in the northeastern Brazil and found that the high consumption of allochthonous items, mainly terrestrial insects and fruits, varied in relation to the hydrological period.

Based on this, we can incorporate the trophic opportunism concept in the feeding analysis of $A$. longimanus. As considered by Gerking (1994), an opportunistic fish is that makes use of an abundant and unusual food source, as in the case studied here, flowers and seeds of forests trees. Some studies also reported significant seasonal differences in fish diet, suggesting 


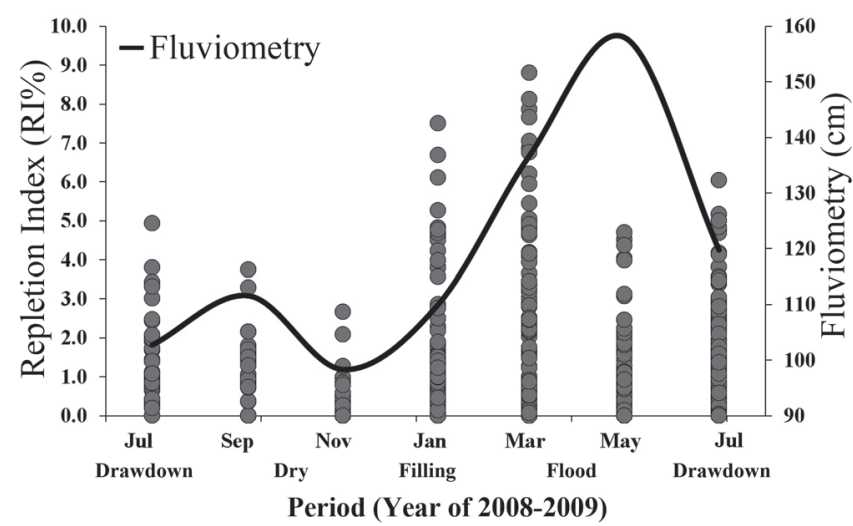

Fig. 5. Repletion index (RI\%) of Auchenipterichthys longimanus from rivers of National Forest of Caxiuanã (PA, Brazil) related to hydrological periods.

that the items are consumed due to greater availability, characterizing them as opportunistic feeders (Abelha \& Goulart, 2004; Ceneviva-Bastos \& Casatti, 2007; Rezende \& Mazzoni, 2003, Esteves \& Aranha, 1999)

These variations are relevant because the food supply is not static, particularly in tropical biotopes, suggesting the trophic plasticity of fish, as has been classically demonstrated in the literature (e.g. Andrian et al., 1994; Abelha et al., 2001). Ringuelet (1942) has already noticed that to understand the feeding habits of a species, we must analyze all possible variations brought by the environment. The most current studies, which include trophic studies in fish, have generally taken into account some of these variations, such as hydrological period (Claro-Jr. et al., 2004; Santos, 2005; LuzAgostinho et al., 2009), food availability (Vidotto-Magnoni \& Caralho, 2009), intra and interspecific relationships (Piorski et al., 2005; Fugi et al., 2008), amongst others.

Although some studies have been addressed the trophic ecology of auchenipterids fish (Ortêncio-Filho et al., 2001; ClaroJr. et al., 2004; Pouilly et al., 2004; Krumme et al., 2004; Santos, 2005; Luz-Agostinho et al., 2009), these studies did not totally focus at auchenipterids or cover only few species, showing there may still be much to learn about the feeding habits of these catfishes. Thus, our study provides important information to increase the biological knowledge about auchenipterids trophic ecology. These parameters are highly relevant to compose the management plan for the Caxiuanã National Forest (still not documented), besides characterizing the riparian forest environments as fundamental in the maintenance and conservation of natural populations of fish in the region.

\section{Acknowledgements}

We are grateful to the Fundação Grupo O Boticário de Proteção à Natureza (process n ${ }^{\circ}$ 0799/20082), the Programa de Pesquisa em Biodiversidade (PPBio/Caxiuanã) and CNPq for financial support. We also thank CAPES, for its financial support through the Programa Nacional de Cooperação Acadêmica (PROCAD/UFPA; process nº 23038.042984/
2008-30), the Estação Científica Ferreira Penna (ECFPn/ MPEG) for logistical support, besides to Benedito Brazão and Renato Calisto for the field assistance. Finally, we thank Lilian Casatti for suggestions on the statistical analysis.

\section{Literature Cited}

Abelha, M. C. F., A. A. Agostinho \& E. Goulart. 2001. Plasticidade trófica em peixes de água doce. Acta Scientiarum, 23: 425-434.

Abelha, M. C. F. \& E. Goulart. 2004. Oportunismo trófico de Geophagus brasiliensis (Quoy \& Gaimard, 1824) (Osteichthyes, Cichlidae) no reservatório de Capivari, Estado do Paraná, Brasil. Acta Scientiarum (Biological Sciences), 26: 37-45.

Andrian, I. F. \& G. Barbieri. 1996. Espectro alimentar e variações sazonal e espacial da composição da dieta de Parauchenipterus galeatus Linaeus, 1766, (Siluriformes, Auchenipteridae) na região do reservatório de Itaipu, PR. Revista Brasileira de Biologia, 56: 409-422.

Andrian, I. F., C. R., Costa-Döria, G. Torrente \& C. M. L. Ferretti. 1994. Espectro alimentar e similaridade na composição da dieta de quatro espécies de Leporinus (Characiformes, Anostomidae) do rio Paraná, Brasil. Revista Unimar, 16: 97-106.

Ballesteros, T. M., M. Torres-Mejia \& M. P. Ramírez-Pinilla. 2009. How does diet influence the reproductive seasonality of tropical freshwater fish? A case study of a characin in a tropical mountain river. Neotropical Ichthyology, 7: 693-700.

Barnes, C., D. Maxwell, D. C. Reuman \& S. Jennings. 2010. Global patterns in predator-prey size relationships reveal size dependency of trophic transfer efficienc. Ecology, 91: 222-232.

Barthem, R. B. \& M. Golding. 2007. An Unexpected Ecosystem: The Amazon revealed by the fisheries. Lima Amazon Conservation Association (ACA), Missouri, Botanical Garden Press, 241p.

Carvalho, F. M. \& E. Kawakami. 1984. Aspectos da biologia de Tocantinsia depressa (Siluriformes, Auchenipteridae). Amazoniana, 8: 327-337.

Ceneviva-Bastos, M. \& L. Casatti. 2007. Oportunismo alimentar de Knodus moenkhausii (Teleostei: Characidae): uma espécie abundante em riachos do noroeste do Estado de São Paulo, Brasil. Iheringia (Série Zoológica), 97: 7-15.

Clarke, K. R. \& R. N. Gorley. 2006. PRIMER v6: User Manual/ Tutorial. Plymouth, Primer-E, 190p.

Clarke, K. R. \& R. M. Warwick. 2001. Change in marine communities: an approach to statistical analysis and interpretation. Plymouth, Plymouth Marine Laboratory, 859p.

Claro-Jr., L., E. Ferreira, J. A. Zuanon \& C. Araujo-Lima. 2004. O efeito da floresta alagada na alimentação de três espécies de peixes onívoros em lagos de várzea da Amazônia central, Brasil. Acta Amazonica, 34: 133-137.

Costa, M. L., D. C. Kern, H. Behling, \& M. S. Borges. 2002. Geologia. Pp. 179-205. In: Lisboa, P. L. B. (Org.). Caxiuanã: populações tradicionais, meio físico e diversidade biológica. Belém, Museu Paraense Emílio Goeldi, 734p.

Esteves, K. E. \& J. M. R. Aranha. 1999. Ecologia Trófica de peixes de riacho. Pp. 157-182. In: Caramaschi, E. P., R. Mazzoni \& P. R. Peres-Neto (Eds.). Ecologia de peixes de riachos. Série Oecologia Brasiliensis, vol. 11. Rio de Janeiro, Brasil, 260p.

Ferraris Jr., C. J. 2003. Family Auchenipteridae. In: Reis, R. E., S. O. Kullander \& C. J. Ferraris Jr. (Eds.). Check List of the Freshewater fishes of South and Central America. Porto Alegre, EDIPUCRS, 742p.

Ferraris Jr., C. J., R. P. Vari \& S. J. Raredon. 2005. Catfishes of the genus Auchenipterichthys (Osteichthyes: Siluriformes: 
Auchenipteridae): a revisionary study. Neotropical Ichthyology, 3: 89-106.

Freitas, T. M. S. 2010. Aspectos ecológicos do cachorro-de-padre Auchenipterichthys longimanus (Siluriformes: Auchenipteridae) em igarapés da Amazônia Oriental, Pará, Brasil. Dissertação de Mestrado, Universidade Federal do Pará/Museu Paraense Emílio Goeldi, 106p.

Fugi, R., K. D. G. Luz-Agostinho, \& A. A. Agostinho, A. A. 2008. Trophic interaction between an introduced (peacock bass) and a native (dogsh) piscivorous sh in a Neotropical impounded river. Hydrobiologia, 607: 143-150.

Gerking, S. D. 1994. Feeding ecology of fish. California: Academic Press, 416p.

Gomiero, L. M., A. G. Manzatto \& F. M. S. Braga. 2008. The role of riverine forests for food supply for the omnivorous fish Brycon opalinus Cuvier, 1819 (Characidae) in the Serra do Mar, southeast Brazil. Revista Brasileira de Biologia, 68: 321-328.

Gottsberger, G. 1978. Seed dispersal by fish in the inundated regions of Humaitá. Amazonia. Biotropica, 10: 170-183.

Goulding, M. 1980. The fishes and the forest. Explorations in Amazonian natural history. California, University of California Press, 280p.

Hammerschlag, N., D. Ovando \& E. J. Serafy. 2010. Seasonal diet and feeding habits of juvenile fishes foraging along a subtropical marine ecotone. Aquatic Biology, 9: 279-290.

Hida, N., J. G. Maia, M. Hiraoka, O. Shimm \& M. Nobuaki. 1999. River water level changes of the Amazon Estuary: at Breves, Caxiuanã and Abaetetuba. Manaus'99 - Hydrological and Geochemical Processess in Large Scale River Basins, p.1-9.

Hurlbert, S. H. 1978. The measurement of niche overlap and some relatives. Ecology, 59: 67-77.

Hynes, H. B. N. 1950. The food of fresh water Sticklebacks (Gasterosteus aculeatus and Pygosteus pungitius), with a review of methods used in studies of the fishes. Journal of Animal Ecology, 19: 36-58.

Hyslop, E. J. 1980. Stomach contents analysis: a review of methods and their application. Journal of Fish Biology, 17: 411-429.

Kawakami, E., G. Vazzoler. 1980. Método gráfico e estimativa de índice alimentar aplicado no estudo de alimentação de peixes. Boletim do Instituto Oceanográfico, 29: 205-207.

Krumme, U., U. Saint-Paul \& H. Rosenthal. 2004. Tidal and diel changes in the structure of a nekton assemblage in small intertidal mangrove creeks in northern Brazil. Aquatic Living Resources, 17: 215-229.

Layman, C. A., J. P. Quattrochi, C. M. Peyer \& J. E. Allgeier. 2007. Niche width collapse in a resilient top predator following ecosystem fragmentation. Ecology Letters, 10: 937-944.

Lin, D. S. C. \& E. P. Caramaschi. 2005. Responses of the fish community to the flood pulse and siltation in a floodplain lake of the Trombetas River, Brazil. Hydrobiologia, 545: 75-91.

Lowe-McConnell, R. H. 1987. Ecological studies in tropical fish communities. New York, Cambridge University Press, 381p.

Luz-Agostinho, K. D. G., A. A. Agostinho, L. C. Gomes \& H. F. Júlio Jr. 2009. Influence of flood pulses on diet composition and trophic relationships among piscivorous sh in the upper Paraná River floodplain. Hydrobiologia 607:187-198.

Mannheimer, S., G. Bevilacqua, E. P. Caramaschi \& F. R. Scarano. 2003. Evidence for seed dispersal by the catfish Auchenipterichthys longimanus in an Amazonian lake. Journal of Tropical Ecology, 19: 215-218.

Merona, B., G. M. Santos \& R. G. Almeida. 2001. Short term effects of Tucuruí Dam (Amazonia, Brazil) on the trophic organization of fish communities. Environmental Biology of Fishes, 60: 377-392.
Montag, L. F. A. 2006. Ecologia, Pesca e Conservação da Comunidade de Peixes na Floresta Nacional de Caxiuanã (Municípios de Melgaço e Portel, Pará, Brasil). Tese de Doutorado, Universidade Federal do Pará/Museu Paraense Emílio Goeldi, 140p.

Montag, L. F. A., T. M. S. Freitas, W. B. Wosiaki \& R. B. Barthem. 2008. Os peixes da Floresta Nacional de Caxiuanã (municípios de Melgaço e Portel, Pará - Brasil). Boletim do Museu Paraense Emílio Goeldi, Ciências Naturais, 3: 11-34.

Ortêncio-Filho, H., N. S. Hahn, R. Fugi \& M. R. Russo. 2001. Aspectos da alimentação de Glanidium ribeiroi (Haseman, 1911) (Teleostei, Auchenipteridae), espécie endêmica do rio Iguaçu, PR. Acta Limnologica Brasiliensia, 13: 85-92.

Piorski, N. M., J. R. L. Alves, M. R. B. Machado \& M. M. F. Correia. Alimentação e ecomorfologia de duas espécies de piranhas (Characiformes: Characidae) do lago de Viana, estado do Maranhão, Brasil. Acta Amazonica, 35: 63-70.

Pouilly, M., T. Yonoki, C. Rosales \& L. Torres. 2004. Trophic structure of fish assemblages from Mamoré River floodplain lakes (Bolivia). Ecology of Freshwater Fish, 13: 245-257.

Rezende, C. F. \& R. Mazzoni. 2003. Aspectos da alimentação de Bryconamericus microcephalus (Characiformes, Tetragonopterinae) no córrego Andorinha, Ilha Grande, RJ. Biota Neotropica, 3: 1-6.

Ringuelet, R. 1942. Ecologia alimentícia del pejerrey Odonthestes bonariensis con notas limnológicas sobre la laguna Chascómus. Revista del Museo de La Plata, 2: 427-461.

Rodriguez, M. A., S. E. Richardson \& W. M. Lewis-Jr. 1990. Nocturnal behavior and aspects of the ecology of a driftwood catfish, Entomocorus gameroi (Auchenipteridae). Biotropica, 22: 435-438.

Romesbeirg, H. C. 1984. Cluster Analisys for Researchers. Belmont, Liftime Learming Publications, 334p.

Saint-Paul, U., J. Zuanon, M. A. V. Correa, M. Garcia, N. N. Fabre, U. Berger \& W. J. Junk. 2000. Fish communities in central Amazonian white and blackwater floodplains. Environmental Biology of Fishes, 57: 235-250.

Santos, A. C. A. 2005. Ecologia alimentar do molé, Trachelyopterus galeatus Linnaeus, 1766 (Siluriformes, Auchenipteridae), em trechos inferiores dos rios Santo Antônio e São José (Chapada Diamantina, Bahia). Sitientibus Série Ciências Biológicas, 5: 93-98.

Santos, E. P. 1979. Dinâmica de populações aplicada à pesca e piscicultura. São Paulo, HUCITEC, 129p.

Tófoli, R. L., N. S. Hahn, G. H. Z. Alves \& G. C. Novakowski. 2010. Uso do alimento por duas espécies simpátricas de Moenkhausia (Characiformes, Characidae) em um riacho da Região CentroOeste do Brasil. Iheringia (Série Zoológica), 100: 201-206.

Vidotto-Magnoni, A. P. \& E. D. Carvalho. 2009. Aquatic insects as the main food resource of fish the community in a Neotropical reservoir. Neotropical Ichthyology, 7: 701-708.

Waldhoff, D., U. Saint-Paul \& B. Furch. 1996. Value of fruits and seeds from the floodplain forests of Central Amazonia as food resource for fish. Ecotropica, 2: 143-156.

Winemiller, K. O. 1989. Patterns of variation in life history among South American fishes in seasonal environments. Oecologia, 81:225-241.

Wootton, R. J. 1998. Ecology of teleost fishes. Boston, Kluwer Academic Publishers, 396p.

Zavala-Camin, L. A. 1996. Introdução aos estudos sobre alimentação natural de peixes. Maringá, EDUEM, 129p.

Submitted May 10, 2010

Accepted June 13, 2011

Published September 16, 2011 